\section{Ground Application of Overdoses of Manganese Have a Therapeutic Effect on Sweet Orange Trees Infected with Candidatus Liberibacter asiaticus}

\author{
Flavia T. Zambon \\ Department of Horticulture, University of Florida, Citrus Research and \\ Education Center, 700 Experiment Station Road, Lake Alfred, FL 33850
}

Davie M. Kadyampakeni

Soil and Water Sciences Department, University of Florida, Citrus Research and Education Center, 700 Experiment Station Road, Lake Alfred, FL 33850

\author{
Jude W. Grosser ${ }^{1}$ \\ Department of Horticulture, University of Florida, Citrus Research and \\ Education Center, 700 Experiment Station Road, Lake Alfred, FL 33850
}

Additional index words. Citrus sinensis, controlled-release fertilizer, Huanglongbing, macronutrients, micronutrients, soil acidification

\begin{abstract}
There is accumulating evidence that root system collapse is a primary symptom associated with Huanglongbing (HLB)-induced tree decline, especially for commercial sweet orange and grapefruit trees on Swingle and Carrizo rootstocks. Maintaining root health is imperative to keep trees productive in an HLB-endemic environment. Preliminary greenhouse and field studies have shown that HLB-impacted trees had secondary and micronutrient deficiencies that were much greater in the roots than in the leaves, and that treatments containing three-times the recommended dose of manganese (Mn) improved tree health and growth and increased feeder root density in greenhouse trees. These results suggested that trees in an HLB-endemic environment have higher specific micronutrient requirements than those currently recommended. To test this hypothesis, established Vernia sweet orange grafted onto rough lemon rootstock trees were divided into eight supplemental CRF nutrition treatments (including twotimes and four-times the recommended doses of $\mathrm{Mn}$ and boron) using a randomized complete block design in a commercial grove in St. Cloud, FL. The following supplemental nutrition treatments were used: no extra nutrition (control); Harrell'sSt. Helena mix $0.9 \mathrm{~kg}$ per tree; Harrell's with $32 \mathrm{~g}$ of Florikan polycoated sodium borate (PSB) per tree; Harrell's with $90 \mathrm{~g}$ of TigerSul ${ }^{\circledR}$ Mn sulfate (MS) per tree; Harrell's with $32 \mathrm{~g}$ of PSB and $90 \mathrm{~g}$ of MS per tree; $180 \mathrm{~g}$ of MS per tree; $64 \mathrm{~g}$ of PSB per tree; and $180 \mathrm{~g}$ of MS plus $64 \mathrm{~g}$ of PSB per tree applied every 6 months since Fall 2015. Leaf and soil nutritional analyses were performed in Mar. 2017, Sept. 2017, and May 2018; a quantitative polymerase chain reaction was performed for Candidatus Liberibacter asiaticus (CLas) titer estimation in Nov. 2017. Significantly higher cycle threshold (Ct) values indicating reduced $C$ Las bacterial populations were observed in trees that received the higher doses of $\mathrm{Mn}$, especially those receiving four-times the recommended dosage of Mn (180 $\mathrm{g}$ Mn). Many trees exhibited Ct values of 32 or more, indicating a nonactive infection. Fruit yields of these trees were also increased. No significant differences in juice characteristics, canopy volume, and trunk section area were found between control plants and plants treated with $180 \mathrm{~g} \mathrm{Mn}$. Soil and leaf nutrients $\mathrm{B}, \mathrm{K}, \mathrm{Mn}$, and $\mathrm{Zn}$ were significantly different among treatments at various times during the study. Our results strongly suggest that overdoses of Mn can suppress $C$ Las bacterial titers in sweet orange trees on rough lemon rootstock, thus providing a therapeutic effect that can help restore tree health and fruit yields. This response was not observed when Mn and B were combined in the overdose, suggesting an antagonistic effect from $B$ on Mn metabolism. When an overdose of $\mathrm{Mn}$ is used, biological functions and tree tolerance lost due to nutritional imbalances caused by HLB might be restored. Further studies are needed to elucidate which metabolic pathways are altered by comparing overdosed and conventionally fertilized HLB-impacted trees and to determine if the observed therapeutic effects can be achieved in trees grafted to other important commercial rootstocks.
\end{abstract}

Plant nutrient management is one of the most basic practices used for crop production and environmental sciences. Acquisition of nutrients by feeder roots is crucial for the ents such as chemical or organic fertilizers is routine for growers, and it is part of nutrien recycling. To reach maximum growth and overcome stresses, plants develop a relationship with soil microbes (Chen et al., 2014; Jacoby et al., 2017; Navarro et al., 2011). Soil microbes change the ionic status of minerals that plants cannot take-up in molecular form during a process called mineralization (Sattelmacher et al., 1982). The presence of nutrients in ionic form can lead to competition for the same exchange in soil colloid sites by ions of similar sizes, thereby interfering with the absorption, adsorption, and transport of a specific ion and/or a similar chemical-physical structure group (Fageria, 2001).

Citrus are among the most valuable crops worldwide. Since 2005, Florida citrus production has been affected by yellow dragon disease, which is commonly known as citrus greening or Huanglongbing (HLB) (Halbert, 2005; USDA-NASS, 2017). HLB is presumably caused by a fastidious bacterium [Candidatus Liberibacter asiaticus (CLas)] transmitted by the Asian Citrus Psyllid (Diaphorina citri). HLB symptoms include blotchy mottled leaves, starch accumulation in leaves, zinc-like deficiency symptoms, misshapen fruit, low juice quality, high fruit drop rate, decreased root biomass, callose and p-protein deposition in phloem sieve pores, and twig dieback (Bové, 2006; Cimò et al., 2013; Etxeberria et al., 2009; Johnson et al., 2014; Kim et al., 2009). As a result of the presence of $C$ Las, nutrient imbalance has been reported, thus aggravating the functional status and physiological status of an already photoassimilate-depleted plant (Nwugo et al., 2013; Spann and Schumann, 2009). Nutrient imbalance causes several drawbacks, especially the deficiency of micronutrients known to be cofactors in enzymatic reactions that protect cell integrity (Hänsch and Mendel, 2009) from excessive reactive oxygen species (ROS) when infected with $C$ Las (Pitino et al., 2017).

Several approaches have been reported to improve the health status of HLB-affected plants, such as an overdose of foliar sprays with essentials nutrients (Morgan et al., 2016) and soil acidification, resulting in corresponding increases in root density and yield (Graham, 2016). However, the low mobility of some ions does not address localized nutrient deficiency in roots infected with CLas (Johnson et al., 2014). The use of polymer-coated or clay-coated products as an alternative to traditional fertilizer application (fertigation/dry granular fertilizer) has increased recently due to its easy application two times per year without the need for incorporation in the soil, synchrony of the release of nutrients and plant demand, and reduced loss of nutrients in the environment (Obreza et al., 2006).

The objective of this study was to balance the nutritional status and alleviate HLB symptoms of field-established sweet orange trees infected with CLas by supplementing a traditional citrus fertilization program with ground-applied, slow-release enhanced nutrition for selected micronutrients, including 
Mn and B at double and quadruple the current recommended doses.

\section{Materials and Methods}

Greenhouse study. We previously conducted a preliminary greenhouse experiment to investigate the potential of micronutrient overdoses to improve the health of CLasinfected trees (Grosser and Barthe, 2015). In the greenhouse, UFR-3 rootstock liners (Nova+Hirado Buntan pummelo $\times$ Cleopatra + Argentine trifoliate orange) were budstickgrafted with HLB-infected Valencia sweet orange. Treatments were established with 10 single-tree replications. Control treatments included either biannual Harrell's ${ }^{\circledR}$ 16-5-10 nursery controlled-release fertilizer (CRF) mix or biweekly liquid fertilizer (Peters). Experimental treatments included biannual treatments of Harrell's CRF mix supplemented with biannual treatments of triple the recommended dose of individual polycoated essential minor elements (Florikan ${ }^{\circledR}$ ), TigerSul micronutrients ${ }^{\circledR}$ (sulfate form of Fe, $\mathrm{Zn}$, and $\mathrm{Mn}$ embedded in clay prills, and a blend of all three products, as recommended by A. Schumann, personal communication), and double the recommended dose of the individual polycoated essential macronutrients. The experiment was performed for 1 year. Effects on tree health, tree growth, root mass, soil plant analysis development (SPAD), leaf and root nutritional analyses, and leaf and root Liberibacter titers were measured.

Field study. Mature 10-year-old midseason 'Vernia' sweet oranges [Citrus sinensis (L.) Osbeck)] grafted onto rough lemon (Citrus jambhiri Lush.) were used in this study performed at Lee Groves in St. Cloud, FL. All trees were HLB-scouted at the beginning of the experiment by trained personal, and $100 \%$ were classified as HLBinfected based on visual observations. Tree density was 375 trees/ha planted every $4.6 \mathrm{~m}$ in rows with $7.6 \mathrm{~m}$ between rows on Myakka fine sand. The soil was classified as sandy soil with $96.5 \%$ sand, $2.2 \%$ clay, and $1.3 \%$ silt. Trees were grown with a standard soluble dry fertilizer program (Supplemental Table 1)

Received for publication 15 Nov. 2018. Accepted for publication 19 Mar. 2019.

We thank Frank Rogers and Jim Baldwin for assistance with controlled-release fertilizer (CRF) applications and yield data collection. This manuscript is dedicated to the late Hall of Fame citrus grower Orie N. Lee, who was responsible for making this trial happen. We also thank Jack Zorn $\left(\right.$ TigerSul ${ }^{\circledR}$ ) and Matt Shook (Harrell's ${ }^{\circledR}$ ) for the donation of CRF products used in the trial. We thank the Citrus Research and Development Foundation for financial support of the greenhouse experiments. Finally, we thank Mike Irey and the Southern Gardens Diagnostic Laboratory for performing our polymerase chain reaction (PCR) samples.

${ }^{1}$ Corresponding author. E-mail: jgrosser@ufl.edu. This is an open access article distributed under the CC BY-NC-ND license (https://creativecommons. org/licenses/by-nc-nd/4.0/). applied four times per year. Supplemental controlled-released fertilizer treatments (Table 1, Supplemental Table 2) were used twice per year, starting in Fall 2015, and were continued throughout this study. Trees were irrigated with microsprinklers. A traditional sweet orange spray program for pest management (only one or two sprays of pesticide per year) was used, but a full psyllid control program was not (grower's/cooperator's decision). The experimental design was a randomized block with 12 plants per treatment (nutrition) subdivided into six plants per replicate. Nutritional replicates were randomly assigned to each subplot, forming four replications per treatment (Fig. 1). A composite of 10 leaves from each of the trees was randomly sampled and sent for quantitative polymerase chain reaction (qPCR) analysis at Southern Gardens Citrus (Clewiston, FL) for confirmation of CLas in Nov. 2017. Plants that showed cycle threshold (Ct) values of 30 or less were considered HLBpositive, those with $\mathrm{Ct}$ values of 32 or more were HLB-negative, and results were inconclusive when the value was between 30 and 32. Soil and leaf samples were collected during Mar. 2017, Sept. 2017, and May 2018 for tissue and soil nutrient concentration analyses. Leaf samples were dried at $65^{\circ} \mathrm{C}$ for $72 \mathrm{~h}$ until dry and then ground with a 20-mesh sieve. The tissue samples were sent to the WaterAg Laboratory (Camila, GA), analyzed using the dry-ashing method, and assessed using inductively coupled plasma atomic emission spectroscopy (ICPAES) to determine elemental concentrations of selected nutrients. The tissue nutrient concentration was expressed as the percentage of the dry tissue biomass (\%). Soil nutrients were extracted using the Mehlich III method and analyzed using the ICP-AES method at the WaterAg Laboratory (Camilla, GA). The nutrient concentration was expressed as nutrient mass per unit of soil mass $\left(\mathrm{mg} \cdot \mathrm{kg}^{-1}\right)$. The tree canopy volume and trunk crosssection area were measured during Mar. 2017, Sept. 2017, and May 2018. The trunk cross-sectional area was calculated assuming a circular shape by measuring the average trunk diameter in the east-west and north-south directions and calculating the trunk crosssection area as $\pi r^{2}$, where $r$ is the mean trunk radius. The canopy volume was calculated based on the following formula for the prolate spheroid shape: $(4 / 3)^{*}(\pi)^{*}($ tree height $/ 2)$ *(mean canopy radius) $)^{2}$ (Obreza and Rouse, 1993). The Brix/acid ratio was calculated in kilograms of solids per box of fruits harvested during Jan. 2018 and was measured at the Citrus Research and Education Center Processing Pilot Plant (Lake Alfred, FL) with a commercial juice extractor (FMC Corp., Philadelphia, PA). A juice color analysis was performed with a GretagMacbeth Color-eye 3100 using Optiview-ProPallete software. The yields of all treatments were collected per replicate plot by Lee Groves personnel for the

Table 1. Slow-release treatments and dosages applied on 10-year-old 'Vernia' trees.

\begin{tabular}{|c|c|c|c|}
\hline Treatment $^{\mathrm{z}}$ & Formulation & Amount $^{y}$ & Product names \\
\hline Control & None & 0 & None \\
\hline Harrell's & $12-3-9$ & $910 \mathrm{~g}$ & Harrell's ${ }^{\circledR}$ St. Helena mix \\
\hline $\begin{array}{l}\text { Harrell's + } \\
2 \times \mathrm{Mn}\end{array}$ & $12-3-9+0.08 \% \mathrm{Mn}$ & $\begin{array}{l}910 \mathrm{~g}+ \\
90 \mathrm{~g}\end{array}$ & $\begin{array}{l}\text { Harrell's }{ }^{\circledR} \text { St. Helena mix }+ \\
\text { TigerSul }{ }^{\circledR} \text { manganese }\left(\mathrm{MnSO}_{4}\right)\end{array}$ \\
\hline $\begin{array}{l}\text { Harrell's + } \\
2 \times \mathrm{B}\end{array}$ & $12-3-9+0.22 \% \mathrm{~B}$ & $\begin{array}{l}910 \mathrm{~g}+ \\
32 \mathrm{~g}\end{array}$ & $\begin{array}{l}\text { Harrell's }{ }^{\circledR} \text { St. Helena Mix }+ \\
\text { Florikan }{ }^{\circledR} \text { polycoated sodium borate } \\
\quad\left\{\mathrm{Na}_{2}\left[\mathrm{~B}_{4} \mathrm{O}_{5}(\mathrm{OH})_{4}\right]\right\}\end{array}$ \\
\hline $\begin{array}{l}\text { Harrell's }+ \\
2 \times \mathrm{Mn}+ \\
2 \times \mathrm{B}\end{array}$ & $12-3-9+0.08 \% \mathrm{Mn}+0.22 \% \mathrm{~B}$ & $\begin{array}{l}910 \mathrm{~g}+ \\
90 \mathrm{~g}+ \\
32 \mathrm{~g}\end{array}$ & $\begin{array}{l}\text { Harrell's }{ }^{\circledR} \text { St. Helena Mix }+ \\
\text { TigerSul }^{\circledR} \text { manganese }+ \\
\text { Florikan }^{\circledR} \text { polycoated sodium borate }\end{array}$ \\
\hline $4 \times \mathrm{Mn}$ & $0.16 \% \mathrm{Mn}$ & $180 \mathrm{~g}$ & TigerSul $^{\circledR}$ manganese \\
\hline $4 \times B$ & $0.44 \% \mathrm{~B}$ & $64 \mathrm{~g}$ & Florikan ${ }^{\circledR}$ polycoated sodium borate \\
\hline $\begin{array}{l}4 \times \mathrm{Mn}+ \\
4 \times \mathrm{B}\end{array}$ & $\begin{array}{l}0.16 \% \mathrm{Mn}+ \\
0.44 \% \mathrm{~B}\end{array}$ & $\begin{aligned} 180 \mathrm{~g}+ \\
64 \mathrm{~g}\end{aligned}$ & $\begin{array}{l}\text { TigerSul }{ }^{\circledR} \text { manganese }+ \\
\text { Florikan }^{\circledR} \text { polycoated sodium borate }\end{array}$ \\
\hline
\end{tabular}

${ }^{\mathrm{z}}$ Treatments in addition to a standard citrus nutrition program.

${ }^{\mathrm{y}}$ Grams per tree.

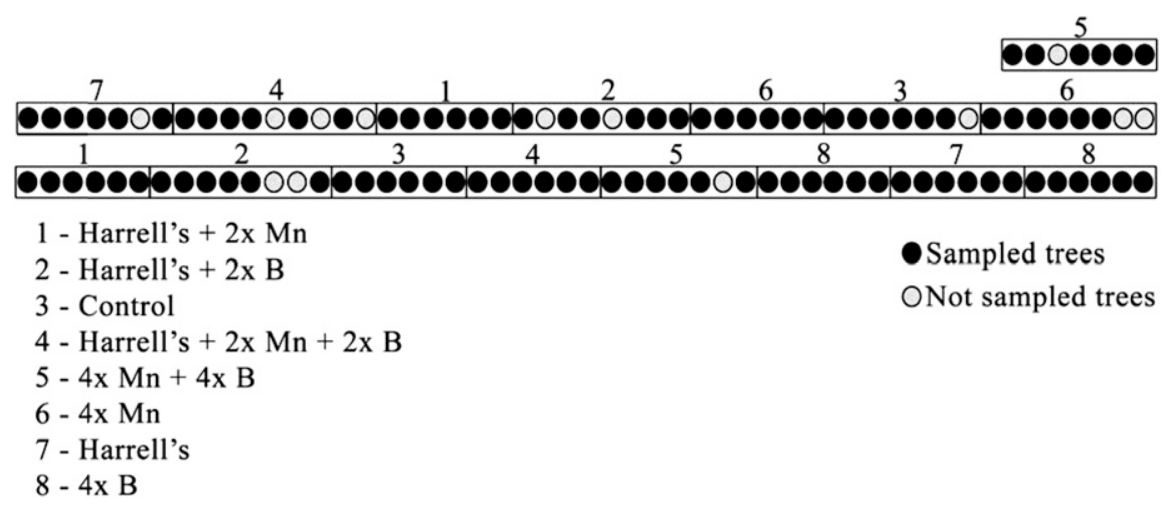

Fig. 1. Diagram of the experimental design and relative tree locations. 
2016, 2017, and 2018 seasons and reported as boxes per acre $(40.5 \mathrm{~kg} /$ box $)$.

Statistical analysis. R-Studio version 1.1.456 was used for statistical analyses.

Valencia grafted onto Carrizo - greenhouse trial

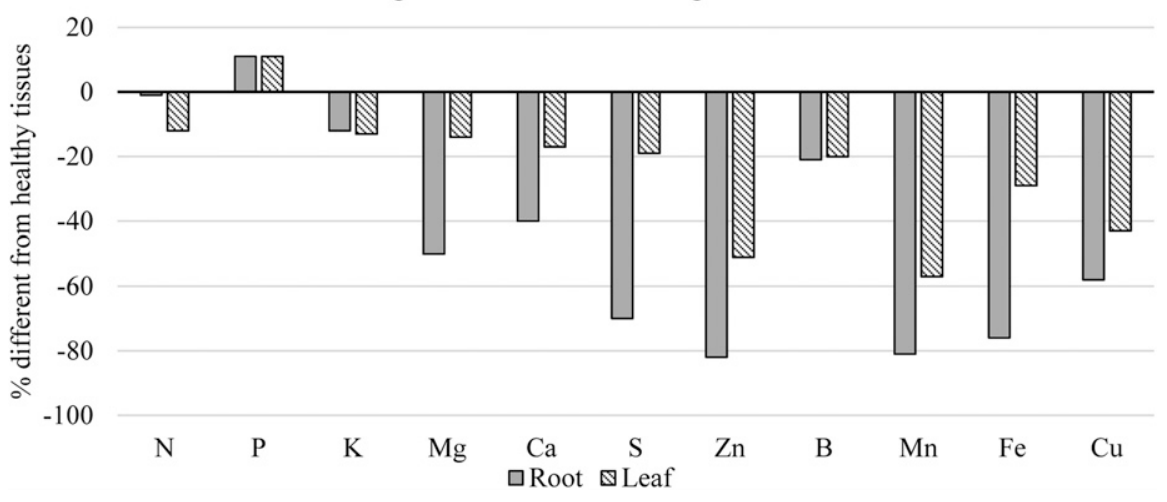

Fig. 2. Nutrient level means for the leaf and root of $C$ Las-infected Valencia/Carrizo (Val/Czo) compared with healthy greenhouse trees. Data (average of 10 trees) are presented in \% differences based on levels in healthy tissues. CLas infections were validated using qPCR.

\section{Root nutrient levels: Valencia grafted onto Swingle - field trial}

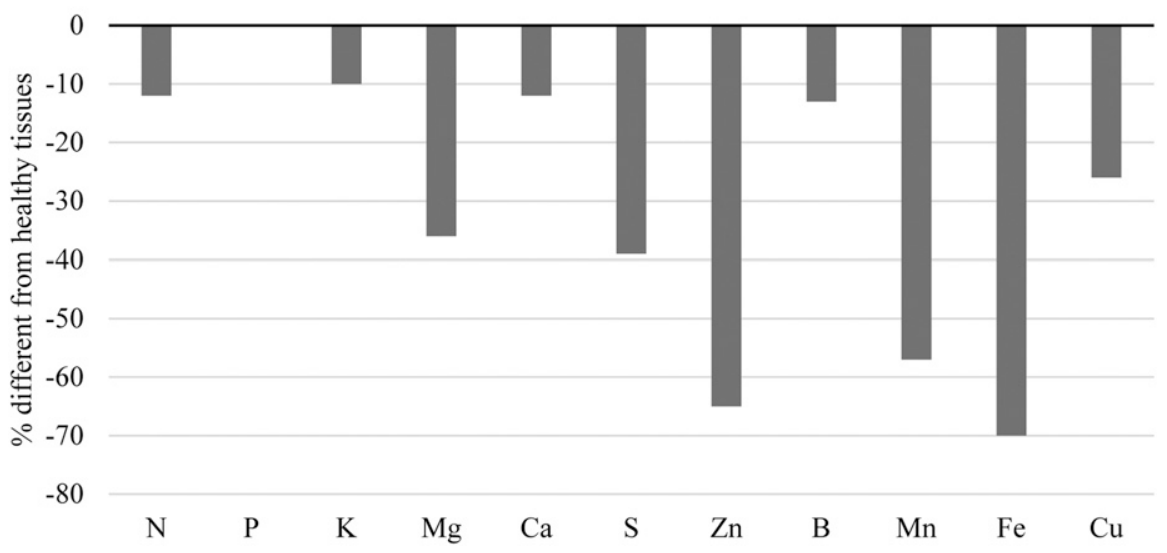

Fig. 3. Root nutrient level means of $C$ Las-infected Valencia/Swingle (Val/SW) field trees (6-10 years old) compared with healthy trees. Nutrient contents (averaged from 10 trees) are presented in $\%$ differences based on levels in healthy tissues. CLas infections were validated using qPCR.
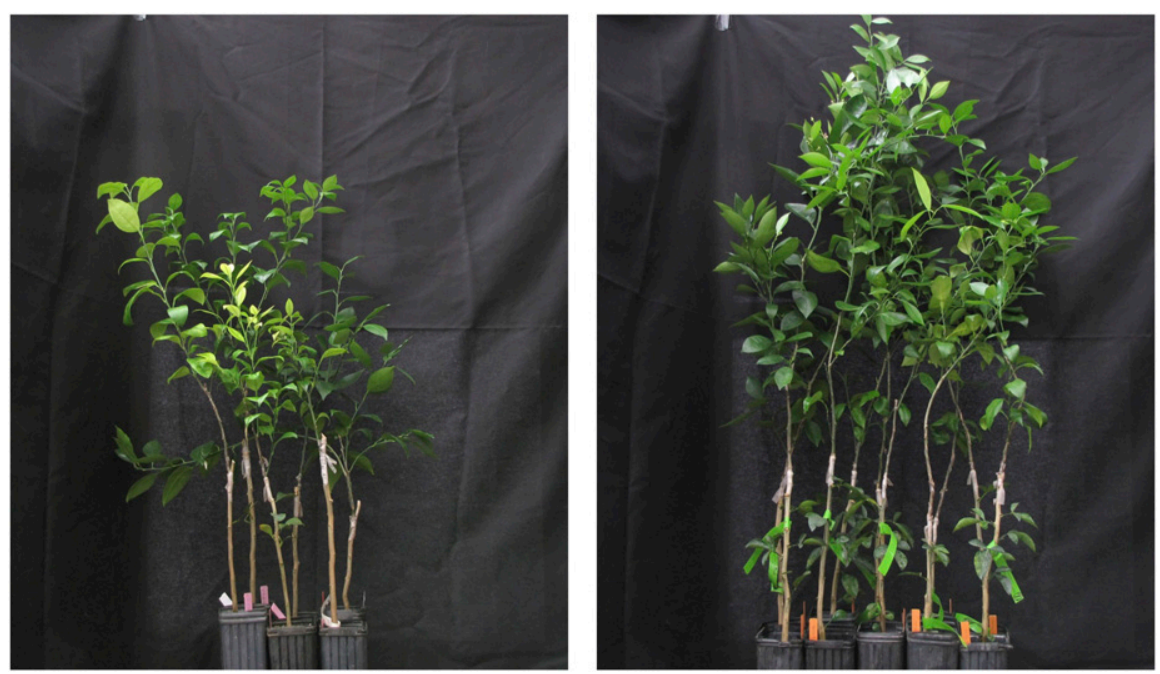

Fig. 4. CLas-infected Valencia/UFR-3 greenhouse trees after 1 year: control standard liquid fertilizer (left) and Harrell's CRF plus triple TigerSul ${ }^{\circledR}$ manganese (right). was performed as a post hoc analysis; when not specifically mentioned, $\alpha \geq 0.05$.

\section{Results and Discussion}

Preliminary data. Preliminary greenhouse and field nutrient analyses were performed before the main experiment reported herein showed that CLas-infected trees have higher levels of micronutrient deficiencies in the roots than in the leaves as compared with healthy trees (Figs. 2 and 3). Zinc, Mn, and $\mathrm{Fe}$ are the micronutrients most impacted by HLB, especially in the roots of infected trees. Soil $\mathrm{pH}$ and micronutrient content do not appear to be responsible for these deficiencies (data not shown).

Several treatments tested during this study significantly improved tree growth and health as compared with the control, especially the triple TigerSul ${ }^{\circledR} \mathrm{Mn}$ and triple polycoated sodium borate treatments. Visual examinations (Figs. 4 and 5) and total root length data generated using winRhizo image analysis (Table 2) showed improved feeder root density and health for the two treatments containing the highest levels of Mn.

Canopy volume and trunk cross-section area. Canopy volume and trunk cross-section area means were not significant between treatments. However, the quadruple $\mathrm{Mn}$ treatment showed a higher canopy volume compared with the that of the treatment with Harrell's ${ }^{\circledR}$ plus double Mn plus double B in Mar. 2017 (Table 3).

Soil nutrient analysis. The soil nutrient analysis showed differences in the potassium (K) content between months for all treatments; these were possibly caused by plant growth during summer and the beginning of fall. The $\mathrm{K}$ soil content during the growing season in Sept. 2017 was statistically significant between treatments because Harrell's treatment resulted in the highest values. Overdoses of B and $\mathrm{Mn}$ treatments had the lowest $\mathrm{K}$ content in soil in Sept. 2017, possibly because K cations have greater valence $(+2)$ compared with the monovalent $\mathrm{K}$ and might have displaced $\mathrm{K}$ from exchange sites (Table 4). Another explanation could be that $\mathrm{K}$ has a greater ionic radius (280 PM) compared with B and Mn ( $<100$ PM), which might have resulted in greater propensity of the tree roots to use the latter two cations, leading to $\mathrm{K}$ losses in the root zone. A similar trend of reduced uptake of $\mathrm{Mn}$ and $\mathrm{B}$ with high concentrations of $\mathrm{K}$ was also observed for rice (Ramadi and Kannan, 1974). A statistical interaction between the treatment and month was observed for $\mathrm{Mn}$ in soil $(P=$ 0.000114) (Fig. 6). As expected, the quadruple $\mathrm{Mn}$ treatment had the highest value of $\mathrm{Mn}$ content in the soil during Sept. 2017 and May 2018. The Mn content for the quadruple B treatment was higher than the treatment with Harrell's ${ }^{\circledR}$ plus double B, suggesting a synergic interaction between $\mathrm{Mn}$ and $\mathrm{B}$, because higher $\mathrm{Mn}$ contents increased with the presence of four-times the recommended dose of $\mathrm{Mn}$ or B in soil. The opposite could be seen for $\mathrm{Mn}$ absolute values of Harrell's ${ }^{\circledR}$ plus double $\mathrm{Mn}$ and Harrell's plus double Mn plus double B treatments, although this was not 
statistically significant. It is possible that lower concentrations of $\mathrm{Mn}$ and $\mathrm{B}$ (twotimes the recommended dose) may interact differently when the soil Mn content is higher. However, the boron content in soil was not significantly different. Except for

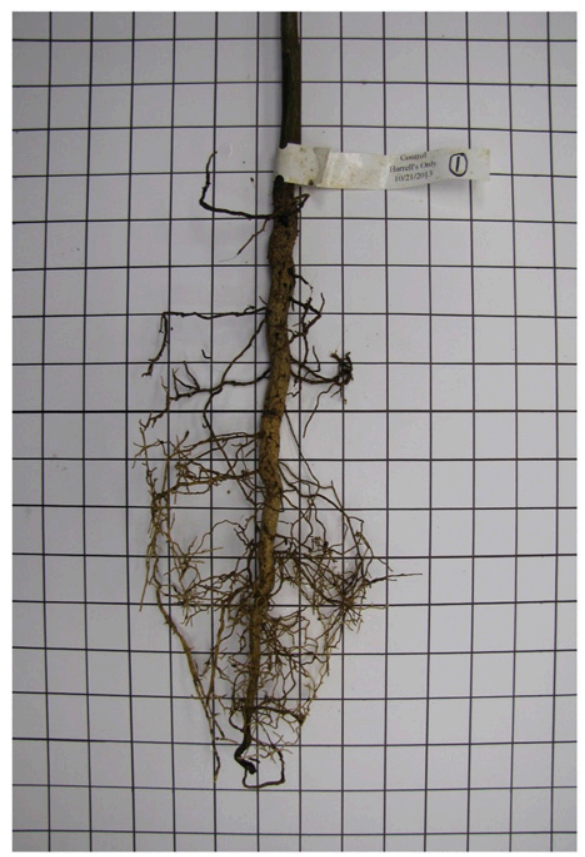

Fig. 5. CLas-infected Valencia/UFR-3 typical root systems: control standard Harrell's CRF fertilizer (left) and Harrell's CRF plus triple TigerSul ${ }^{\circledR}$ manganese (right).

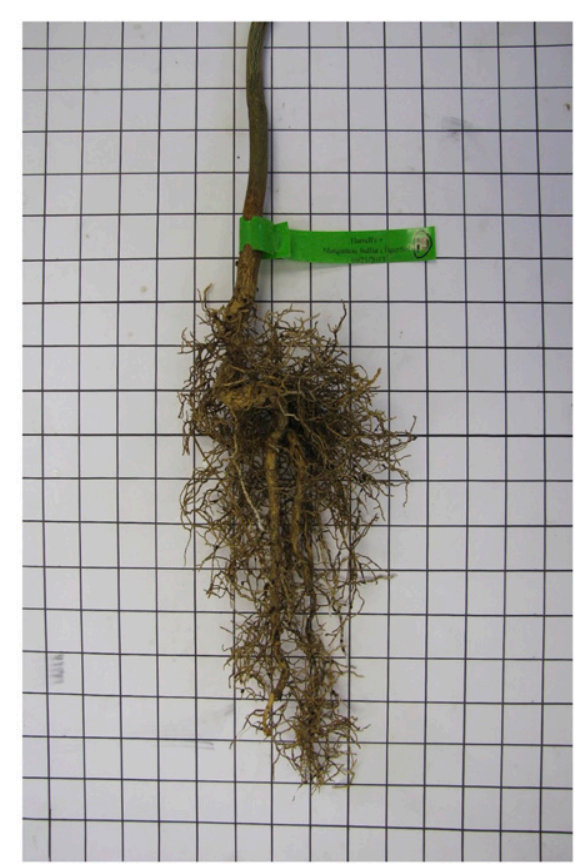

the treatment including Harrell's plus double $\mathrm{Mn}$, the leaf $\mathrm{Mn}$ content remained low $(18-24 \mathrm{ppm})$ or deficient $(<18 \mathrm{ppm})$ with the other treatments during Mar. 2017, but it remained in the optimum range $(25-100$ ppm) during Sept. 2017 and May 2018.
Therefore, it would be ideal to have Mn or micronutrient thresholds for different times of the year because the leaf nutrient content tends to increase during the summer flush (July-September samples), and it tends to decrease when trees remobilize nutrients to fruit and vegetative growth during late fall and early spring, resulting in decreased leaf tissue nutrient concentrations.

Citrus roots are one of the first affected sites when infected with CLas before any foliar symptoms occur (Johnson et al., 2014); this occurs from 6 months to 3 years after the initial infection (Bové, 2006). Transcriptomes of early infected citrus roots showed stress-related genes were differentially regulated (Zhong et al., 2015) and showed downregulation of genes related to oxidative stress (Mittler, 2002). Among the genes involved with oxidative stresses, mitochondria superoxidase dismutase is dependent on Mn availability to reduce the ROS pool in cells (Alscher et al., 2002). ROS are reducing agents that are known to extensively damage cells because of either biotic (a pathogen, such as CLas) or abiotic stresses (such as drought, wind, cold, heat, and nutrient deficiency). Sufficient $\mathrm{Mn}$ in the rhizosphere is critical for scavenging the deadly ROS produced by the presence of CLas. To be actively taken-up by the roots, Mn must be in its reduced form $\left(\mathrm{Mn}^{+2}\right)$ (Gherardi and Rengel, 2003; Marschner, 1995; Pittman, 2005). Reduction of $\mathrm{MnSO}_{4}$ happens by reducing rhizosphere $\mathrm{pH}$, and increasing

Table 2. Effects of nutrient overdoses on CLas-infected Valencia/UFR-3 greenhouse trees after 1 year of treatments. Total root length (cm) was determined by winRhizo washed root image analysis.

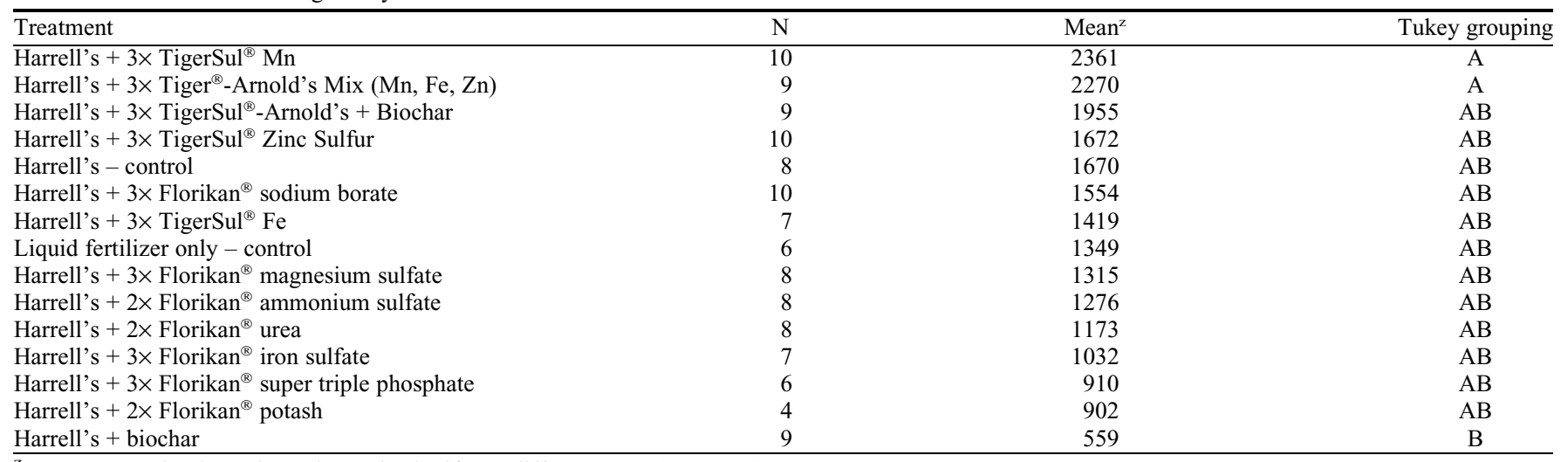

${ }^{\mathrm{z}}$ Means separation by Tukey's honestly significant difference test $(P \leq 0.05)$.

Table 3. Canopy volume $\left(\mathrm{m}^{3}\right)$ and trunk cross-sectional area $\left(\mathrm{cm}^{2}\right)$ for Mar. 2017, Sept. 2017, and May 2018.

\begin{tabular}{|c|c|c|c|c|c|c|c|c|}
\hline \multirow[b]{2}{*}{ Treatment } & \multicolumn{2}{|c|}{ Mar. 2017} & \multicolumn{2}{|c|}{ Sept. 2017} & \multicolumn{2}{|c|}{ May 2018} & \multicolumn{2}{|c|}{ Total averaged $(2 \mathrm{yr})$} \\
\hline & Canopy vol. & $\begin{array}{c}\text { Trunk } \\
\text { cross-section } \\
\text { area }\end{array}$ & Canopy vol. & $\begin{array}{c}\text { Trunk } \\
\text { cross-section } \\
\text { area }\end{array}$ & Canopy vol. & $\begin{array}{c}\text { Trunk } \\
\text { cross-section } \\
\text { area }\end{array}$ & Canopy vol. & $\begin{array}{c}\text { Trunk } \\
\text { cross-section } \\
\text { area }\end{array}$ \\
\hline Harrell's ${ }^{\circledR}$ & $25.5 \mathrm{ab} \mathrm{A}$ & 148.4 a A & 18.54 a C & 180.3 a A & 26.5 a B & $160.05 \mathrm{ab} A$ & 35.27 & 244.37 \\
\hline Control & $24.94 \mathrm{ab} \mathrm{A}$ & 154.9 a A & 19.69 a B & 199.9 a A & $24.95 \mathrm{ab} \mathrm{AB}$ & $191.05 \mathrm{a} \mathrm{A}$ & 34.79 & 272.92 \\
\hline Harrell'$^{\circledR}+2 \times B$ & $23.61 \mathrm{ab} \mathrm{A}$ & 157.3 a B & 23.39 a B & 199.9 a A & $25.00 \mathrm{ab} \mathrm{B}$ & $173.4 \mathrm{ab} \mathrm{AB}$ & 36 & 265.3 \\
\hline Harrell's ${ }^{\circledast}+2 \times M n+2 \times B$ & $17.61 \mathrm{~b} \mathrm{~A}$ & $123.2 \mathrm{a} \mathrm{A}$ & $20.84 \mathrm{a} \mathrm{A}$ & 179.8 a A & $19.8 \mathrm{~b} \mathrm{~A}$ & $134.85 \mathrm{~b} \mathrm{~A}$ & 29.12 & 218.92 \\
\hline
\end{tabular}

${ }^{\mathrm{z}}$ Means separation within months according to Tukey's honestly significant difference test $(P \leq 0.05$; lowercase).

${ }^{\mathrm{y}}$ Means separation between months according to Tukey's honestly significant difference test ( $P \leq 0.05$; uppercase). 


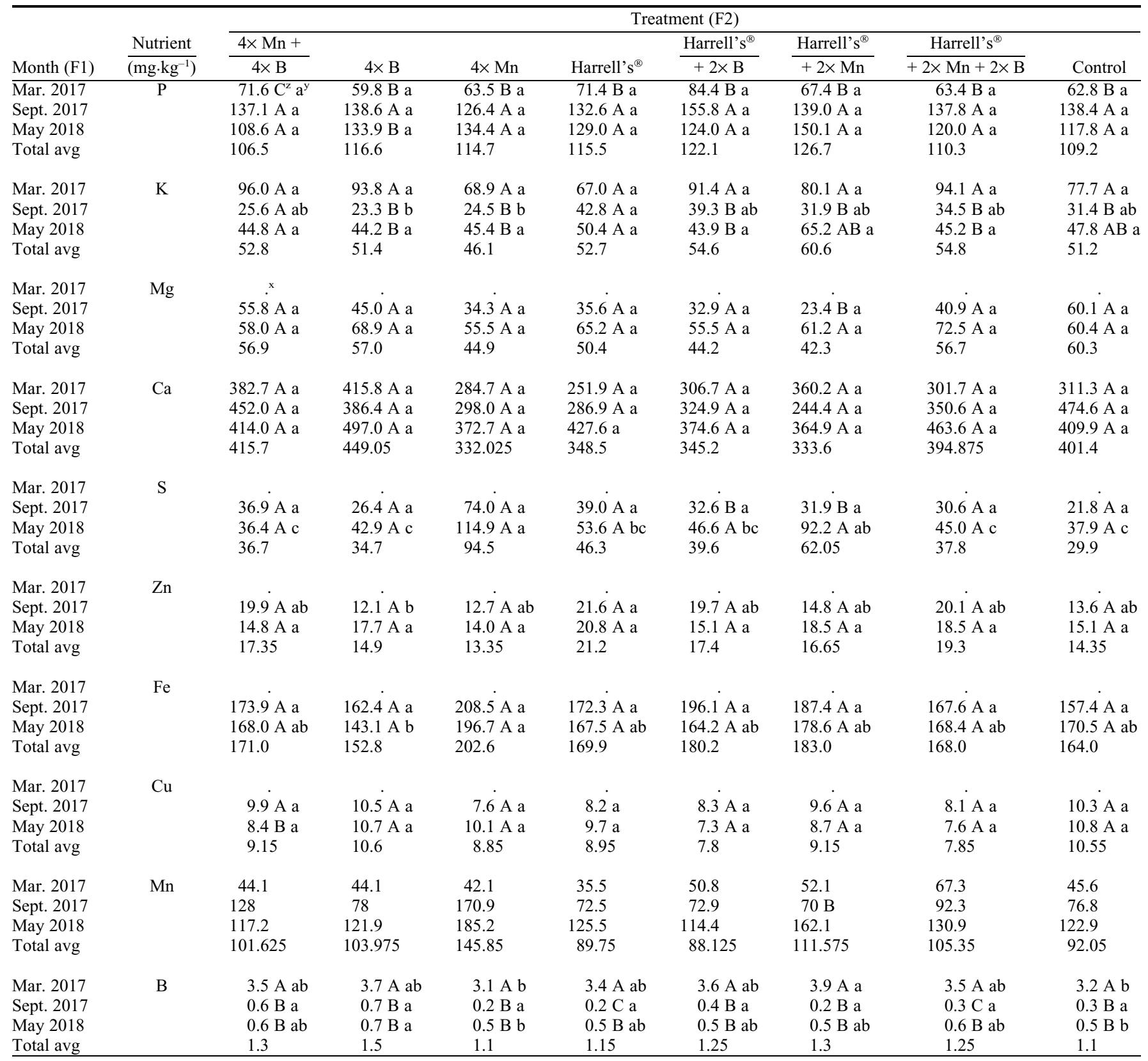

${ }^{\mathrm{z}}$ Means separation between months by Tukey's honestly significant difference test ( $P \leq 0.05$; uppercase).

${ }^{\mathrm{y}}$ Means separation within months by Tukey's honestly significant difference test ( $P \leq 0.05$; lowercase).

${ }^{\mathrm{x}}$ Nutrients not measured for Mar. 2017.

microflora conditions in the rhizosphere assist in reducing $\mathrm{Mn}$ to an available form (Jacoby et al., 2017).

Higher availability of $\mathrm{Mn}$ in the soil profile could have a positive effect on the roots of HLB-infected plants by triggering defense responses against the pathogen because HLB-infected plants have reduced root biomass (Graham et al., 2013). Lower root biomass affects the entire process of water and nutrient uptake, and the plant response to HLB by phloem blocking shortens the distribution of several ions for new growth (Nwugo et al., 2013).

Leaf nutrient analysis. Nitrogen (N), P, K, and $\mathrm{Mg}$ concentrations were statistically different between months (Table 5). Calcium (Ca), $\mathrm{Mn}, \mathrm{Fe}$, and $\mathrm{B}$ concentrations were higher in September, perhaps due to the summer flush during early fall. There was a statistically significant interaction between treatment and month $\left(P=2.01 \mathrm{e}^{-10}\right)$ for boron. Although there was no statistically significant interaction for $\mathrm{Mn}$, its content differed according to treatment over the months.

An accumulation of $\mathrm{Mn}$ was noticed for Harrell's ${ }^{\circledR}$ plus double Mn plus double B and for Harrell's ${ }^{\circledR}$ plus double Mn in Sept. 2017; this increase in Mn content was observed in leaves administered twice the recommended dose of B. The quadruple Mn treatment could have led to toxicity and, therefore, reduced uptake compared with the control and even Harrell's ${ }^{\circledR}$ fertilizer treatment groups (Fig. 7). Doses of four-times that recommended for $\mathrm{Mn}$ and $\mathrm{B}$ also reduced the Mn content in leaves. Double the recommended dose of boron with Harrell's treatment was quasilinear regarding the accumulation of $\mathrm{Mn}$ in leaves over time (Fig. 7). This partially explained the synergic environment for $\mathrm{Mn}$ allocation in leaves when in the presence of twice the recommended dose of $\mathrm{B}$ in the mix. The opposite was seen in the accumulation of B over time in the leaves. Quadruple the recommended dose of $\mathrm{Mn}$ and $\mathrm{B}$ showed leaf B concentrations more than $50 \%$ of the current Florida guidelines regarding the optimal range for $\mathrm{B}\left(200 \mathrm{mg} \cdot \mathrm{kg}^{-1}\right)$ (Fig. 8). Nutrient accumulation from Mar. 2017 to May 2018 and utilization in new meristematic tissues could be the reason why there were high values of B in leaves. Mn could have a synergic effect when used in higher 


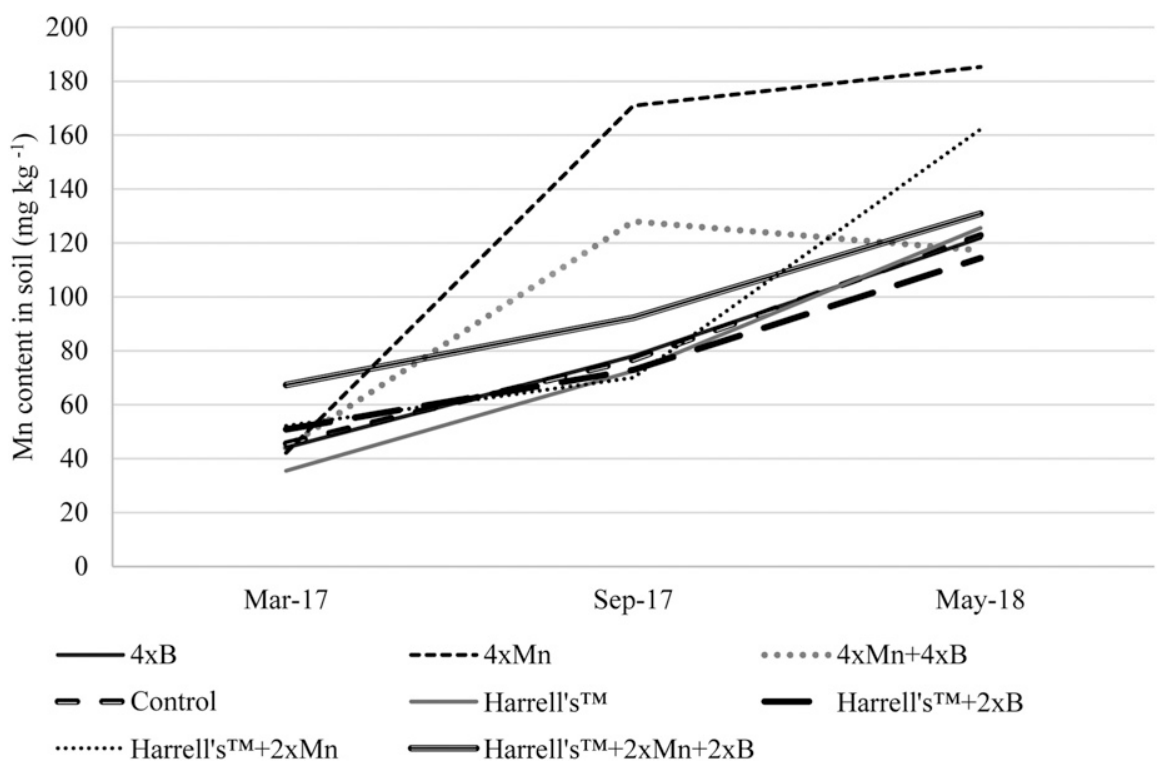

Fig. 6. Interaction plot of months and treatment for manganese content in soil. Statistically significant mean totals are presented. Means separation within months*treatment were determined using Tukey's honestly significant difference test $(P \leq 0.05)$

doses to increase the allocation of B in leaves and when $\mathrm{B}$ is present in the fertilizer mix because the quadruple $\mathrm{Mn}$ treatment alone had B concentrations within the limits for B content in leaves.

Physiologically, boron has a role in tissue growth and is necessary for vascular tissue repair, which is compromised in CLas-infected plants, membrane stability, and metabolism of indole acetic acid, which is a plant hormone responsible for cell multiplication (Blevins, 1998). When B was deficient in squash root apices, Mndependent indole-3-acetic acid oxidase (IAAO) activity was higher compared with that of well-supplied B root tips. Higher IAAO activity might be due to the interaction between B with the IAAO cofactors $\mathrm{Mn}$ and p-coumaric acid. Lower activity of IAAO was observed in B-sufficient plants. By supplementing $\mathrm{Mn}$ in B-sufficient squash root tips, IAAO activity was stimulated, which was an indication that, in presence of $\mathrm{B}$ more $\mathrm{Mn}$ is needed for enzyme activity (Nguyen et al., 1993).

Compared with other nutrition during the same month, statistically lower concentrations of B were found in March and September with quadruple Mn treatment, indicating an antagonistic effect between $\mathrm{B}$ and $\mathrm{Mn}$ ions for allocation inside the cell and uses by the plant (Aref, 2012). It is important to notice that quadruple Mn treatment results in the significantly lowest values for B content in leaves for all the months, which is crucial for normal meristematic growth (Blevins and Lukaszewski, 1998).

Juice attributes and yield data. Juice attributes were not significant across all treatments (Table 6). This could be due to an effect of overlapping root zones from neighboring trees with different treatments; therefore, the effect of nutrients on juice quality was negligible (Castle, 1980, 1977).
No differences in juice quality were found in a similar nutrition study involving asymptomatic and symptomatic 'Hamlin', 'Midsweet', and 'Valencia' juices analyzed in 2007 (Baldwin et al., 2010).

A breakout of post-bloom fruit drop caused by Colletotrichum acutatum during fruiting formation in the 2017 season resulted in decreased yield data across all treatments for that year (Fagan, 1979). Although yield data from three seasons (2016, 2017, and 2018) did not have statistically significant 95\% confidence intervals among treatments (Table 7), 'Vernia' trees that received four-times the recommended doses of $\mathrm{Mn}$ exhibited lower $\mathrm{Ct}$ values compared with the control group (Table 8). During the 2-year trial period, the 12 trees included in the quadruple $\mathrm{Mn}$ treatment group produced more than 10 total field boxes compared with the control trees. A field box $(40.8 \mathrm{~kg} /$ fruit box) of fruit with this quality is currently worth $\approx \$ 17$ (USDA-NASS 2017). Extrapolating this to a per-acre basis at 150 trees per acre would mean that the quadruple $\mathrm{Mn}$ treatment would have the potential to provide more than $\$ 2500$ extra income per acre as compared with the control during the 2-year trial period.

Soil $p H$. Nutrient solubility and availability are closely related to soil $\mathrm{pH}$. Acidification can interfere with oxidation/reduction processes on soil colloids. In an experiment involving six vegetable species, $\mathrm{pH}$ values ranging from 5.5 to 6.5 were ideal for maximum or near-maximum growth (Islam et al., 1980). Florida's irrigation water is naturally alkaline $(\mathrm{pH}>7.0)$ and has high levels of carbonates and bicarbonates of $\mathrm{Ca}$ and $\mathrm{Mg}$. Constant applications of alkaline groundwater sources can increase soil $\mathrm{pH}$ over time, thus altering the availability/ solubility of nutrients, especially micronutrients, and directly affecting plant growth
(Albano et al., 2017). To neutralize groundwater alkalinity, Albano et al. (2017) added sulfuric acid to levels of medium and low alkalinity $\left(3 \mathrm{mEq} \cdot \mathrm{L}^{-1} \mathrm{CaCO}_{3}\right.$ and $1 \mathrm{mEq} \cdot \mathrm{L}^{-1}$ $\mathrm{CaCO}_{3}$, respectively). During our experiment, acidification was achieved by the dissociation of $\mathrm{MnSO}_{4}$ in the soil. The increase in sulfur content in the soil in May 2018 could be observed in all treatments supplied with Mn (Table 4), especially quadruple Mn treatment, by adjusting the $\mathrm{pH}$ values to the best range for nutrient availability (Fig. 9). All treatments with sodium borate involved less than the best $\mathrm{pH}$ for citrus roots in May because the formation of boric acid was increased by the excess boron accumulated in the soil. When in combination with $\mathrm{MnSO}_{4}$, the $\mathrm{pH}$ decreased even more due to the presence of $\left(\mathrm{SO}_{4}\right)^{-2}$ in solution.

HLB confirmation. Using qPCR, CLas detection was performed in Nov. 2017 (Table 8) for all treatments at the Southern Gardens Laboratory. Plants supplied with control nutrition had the highest $\mathrm{Ct}$ values, meaning that more copies of the bacteria were amplified during each cycle (Li et al., 2006; Wang et al., 2006). Plants that received quadruple Mn treatment showed the highest average $\mathrm{Ct}$ value, which was significantly different from plants that received the control treatment. Therefore, higher $\mathrm{Ct}$ values indicated lower genomic copies of the bacteria, suggesting that an overdose of Mn may limit bacterial growth within trees. Applications of four-times the recommended dose of Mn suggested a decrease of inoculum growth and that $\mathrm{Mn}$ could have a role in plant recovery from biotic stress and root damage because it is crucial for enzymatic stress-related processes (Millaleo et al., 2010). High Ct values can be interpreted as a therapeutic effect against $C$ Las in sweet oranges when fertilized with quadruple Mn because of the physiological roles played by $\mathrm{Mn}$ and $\mathrm{B}$ interactions (Tables 4 and 5) in analyzed soil and leaf samples.

Although the accumulation of $\mathrm{Mn}$ in soil during Sept. 2017 and May 2018 could be the reason for the therapeutic effect of the nutrient in HLB-affected trees during the full growth season, the accumulation of $\mathrm{B}$ in leaves with the quadruple Mn treatment was in the range of optimum levels of the mineral element in citrus, which is now reached with regular foliar sprays.

Root decline happens before any HLB symptom in the aerial part of the trees. Moreover, once infected, the plant quickly proceeds to tissue dieback. By supplying mature plants with ground overdoses of micronutrients, we could reduce the inoculum multiplication compared with nutrientdeprived plants when all the essential mineral nutrients were balanced in the optimum range for a mature citrus plant because absolute yield data can prove the usefulness of quadruple Mn treatment. As mentioned, all trees in this trial were on rough lemon rootstock. Ungrafted rough lemon trees have been 


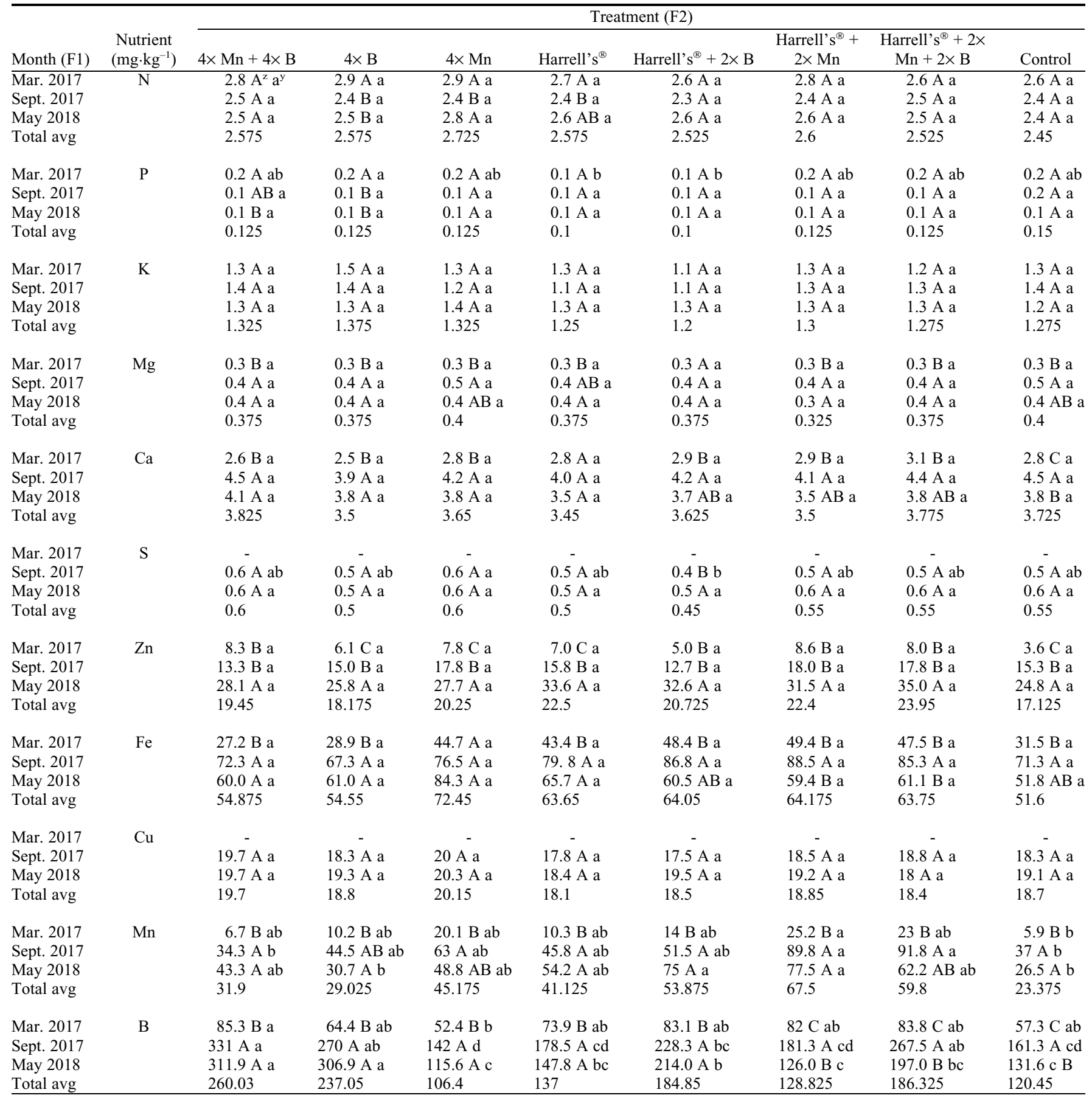

${ }^{\mathrm{z}}$ Means separation between months according to Tukey's honestly significant difference test ( $P \leq 0.05$; uppercase).

${ }^{\mathrm{y}}$ Means separation within months according to Tukey's honestly significant difference test $(P \leq 0.05$; lowercase).

shown to be more tolerant of CLas infection, which is attributed to its ability to quickly regenerate new phloem that bypasses phloem compromised by the infection (Fan et al., 2013). Data from our field experiment suggested that enhanced root nutrition may increase the HLB tolerance of sweet orange trees grafted to rough lemon rootstock, making it a viable candidate for future plantings in areas where HLB is endemic. Testing the effects of micronutrient overdoses (especially $\mathrm{Mn}$ ) on HLB-impacted trees on other important commercial rootstocks is being performed.
To our knowledge, this is the first study to connect ground applications of overdoses of a micronutrient to suppress CLas multiplication and to improve the nutritional status and health status of HLB-affected citrus trees. A constant supply of increased levels of secondary nutrients and micronutrients to roots of HLB-impacted trees clearly improved vascular function and, thus, tree health. The data presented herein suggest the possible benefits of providing levels of Mn to HLBimpacted citrus trees that could be toxic to $C$ Las but that were not toxic to trees. We are now testing overdoses of polycoated $\mathrm{Mn}$ sulfate (6-month release period, Florikan) with various secondary nutrient and micronutrient packages at multiple locations. Further studies regarding the correlation between $\mathrm{Mn}$ and $\mathrm{B}$ in stress-related genes and nutrient uptake channels in the roots could elucidate the roles played by the two essential micronutrients in the era of HLB and citriculture production.

\section{Literature Cited}

Albano, J.P., J. Altland, D.J. Merhaut, S.B. Winson, and P.C. Wilson. 2017. Irrigation water acidification to neutralize alkalinity for nursery crop 


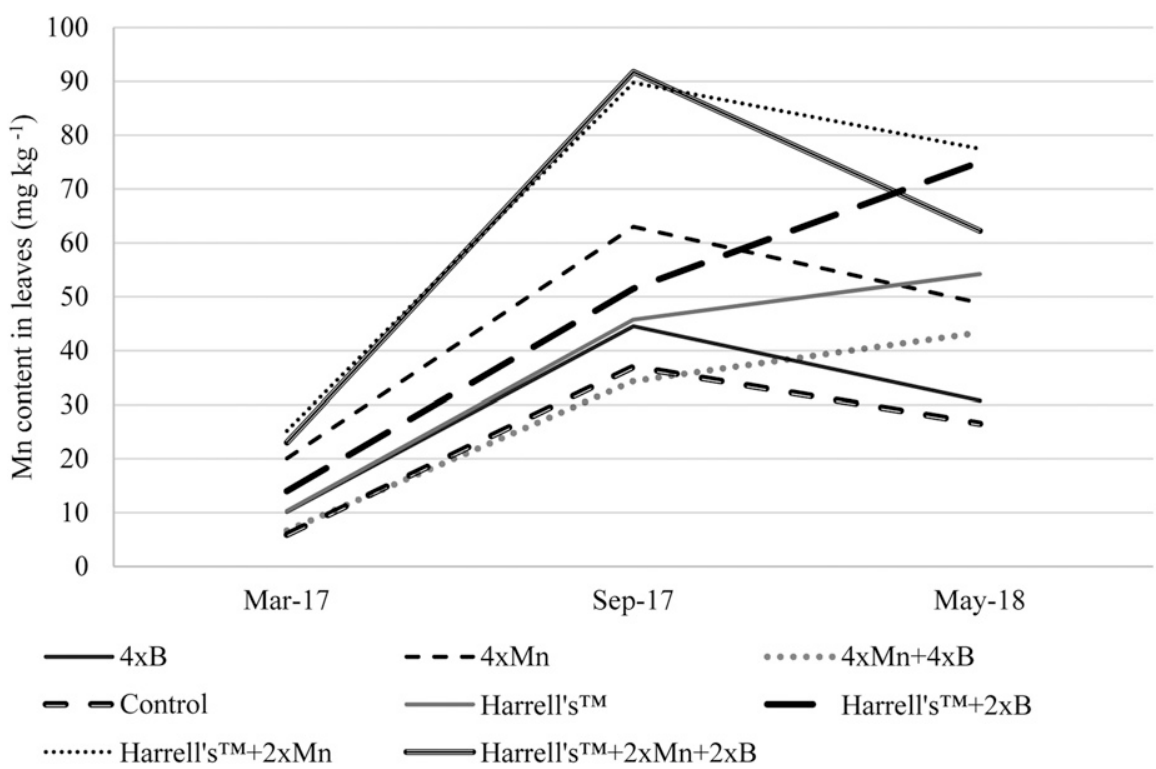

Fig. 7. Manganese content in leaves during Mar. 2017, Sept. 2017, and May 2018. Statistically significant mean totals are presented. Means separation within months were determined using Tukey's honestly significant difference test $(P \leq 0.05)$.

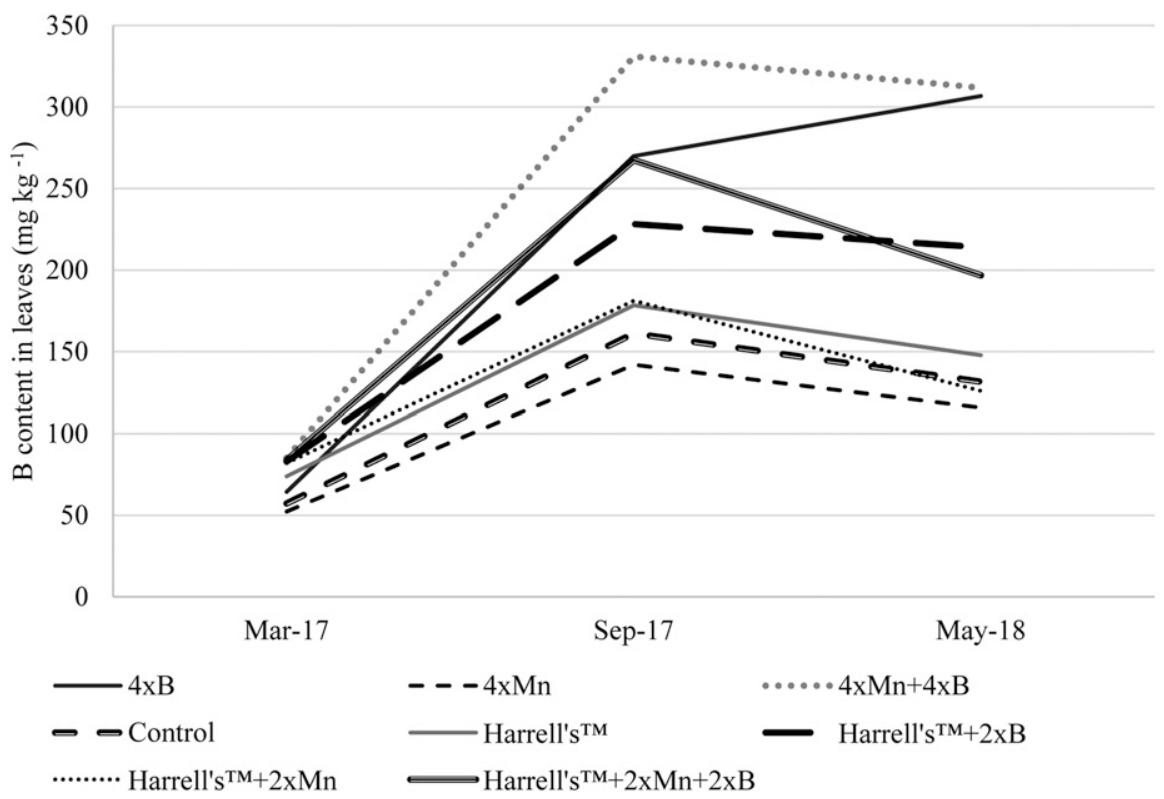

Fig. 8. Boron content in leaves during Mar. 2017, Sept. 2017, and May 2018. Statistically significant mean totals are presented. Means separation within months*treatment were determined using Tukey's honestly significant difference test $(P \leq 0.05)$. production: Substrate $\mathrm{pH}$, electrical conductivity, nutrient concentrations, and plant nutrition and growth. HortScience 52:1401-1405.

Alscher, R.G., N. Erturk, and L.S. Heath. 2002. Role of superoxide dismutases (SODs) in controlling oxidative stress in plants. J. Expt. Bot. 53:1331-1341.

Aref, F. 2012. Manganese, iron and copper contents in leaves of maize plants (Zea mays L.) grown with different boron and zinc micronutrients. Afr. J. Biotechnol. 11:896-903.

Baldwin, E., A. Plotto, J. Manthey, G. Mccollum, J. Bai, M. Irey, R. Cameron, and G. Luzio. 2010. Effect of liberibacter infection (Huanglongbing disease) of citrus on orange fruit physiology and fruit/fruit juice quality: Chemical and physical analyses. J. Agr. Food Chem. 58:12471262.

Blevins, D. and K. Lukaszewski. 1998. Boron in plant structure and function. Annu. Rev. Plant Physiol. Plant Mol. Biol. 49:481-500.

Blevins, D.G. and K.M. Lukaszewski. 1998. Boron in plant structure and function. Annu. Rev. Plant Physiol. Plant Mol. Biol. 49:36-41.

Bové, J.-M. 2006. Huanglongbing: A destructive, newly-emerging, century-old disease of citrus. J. Plant Pathol. 88:7-37.

Castle, W.S. 1977. Root system characteristics of citrus nursery trees. Proc. Annu. Meet. Fla. State Hort. Soc. 90:39-44.

Castle, W.S. 1980. Fibrous root distribution of "Pineapple" orange trees on rough lemon rootstock at three tree spacings. J. Amer. Soc. Hort. Sci. 105:478-480.

Chen, Y.Y., C.Y. Hu, and J.X. Xiao. 2014. Effects of arbuscular mycorrhizal inoculation on the growth, zinc distribution and photosynthesis of two citrus cultivars grown in low-zinc soil. Trees 28:1427-1436.

Cimò, G., R. Lo Bianco, V. Scienze, P. Gonzalez, W. Bandaranayake, E. Etxeberria, and J.P. Syvertsen. 2013. Carbohydrate and nutritional responses to stem girdling and drought stress with respect to understanding symptoms of Huanglongbing in citrus. HortScience 48: 920-928.

Etxeberria, E., P. Gonzalez, D. Achor, and G. Albrigo. 2009. Anatomical distribution of abnormally high levels of starch in HLB-affected Valencia orange trees. Physiol. Mol. Plant Pathol. 74:76-83.

Fagan, H.J. 1979. Postblossom fruit drop, a new disease of citrus associated with a form on Colletotrichum gloeosporioides. Ann. Appl. Biol. 91:13-20.

Fageria, V.D. 2001. Nutrient interactions in crop plants. J. Plant Nutr. 24:1269-1290.

Fan, J., C. Chen, D.S. Achor, R.H. Brlansky, Z.G. Li, and F.G. Gmitter. 2013. Differential anatomical responses of tolerant and susceptible citrus species to the infection of "Candidatus Liberibacter asiaticus". Physiol. Mol. Plant Pathol. 83:69-74.

Gherardi, M.J. and Z. Rengel. 2003. Genotypes of lucerne (Medicago sativa L.) show differential

Table 6. Juice attributes for fruits harvested in Jan. 2018.

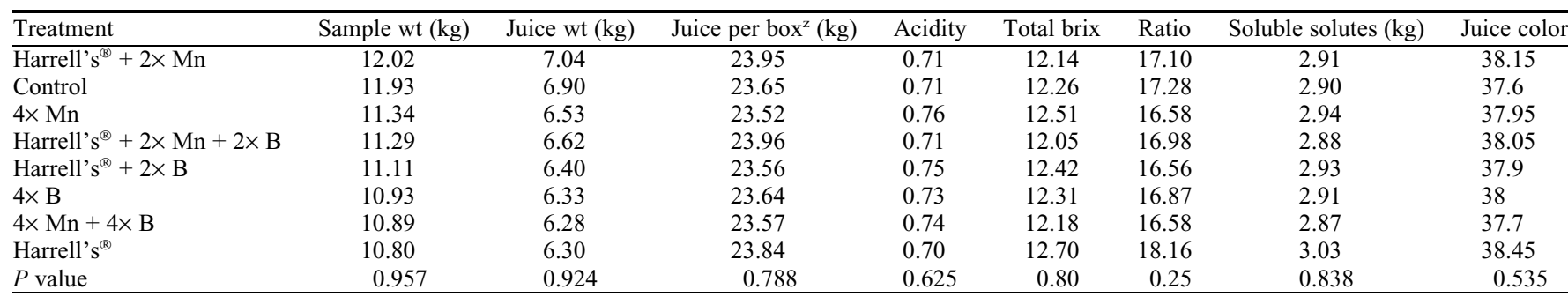

${ }^{\mathrm{z}} \mathrm{A}$ field box contains $40.82 \mathrm{~kg}$ of fruit. 
Table 7. Yield accumulation of 'Vernia' sweet oranges for the 2015, 2016, and 2017 seasons.

\begin{tabular}{|c|c|c|c|c|c|}
\hline \multirow[b]{2}{*}{ Treatment } & \multicolumn{4}{|c|}{ Yield per yr (boxes ${ }^{z}$ per tree) } & \multirow[b]{2}{*}{$P$ value Treatment } \\
\hline & 2016 & $2017^{y}$ & 2018 & Cumulative $^{\mathrm{x}}$ & \\
\hline Control & 1.67 & 0.56 & 1.71 & 27.2 & NS \\
\hline Harrell's ${ }^{\circledR}$ & 1.5 & 1.02 & 1.75 & 33.2 & NS \\
\hline Harrell's $s^{\circledR}+2 \times \mathrm{Mn}$ & 1.5 & 0.83 & 1.54 & 28.4 & NS \\
\hline Harrell's ${ }^{\circledR}+2 \times B$ & 1.92 & 0.83 & 1.71 & 30.5 & NS \\
\hline Harrell's ${ }^{\circledR}+2 \times \mathrm{Mn}+2 \times \mathrm{B}$ & 1.5 & 0.94 & 1.71 & 31.8 & NS \\
\hline $4 \times \mathrm{Mn}$ & 1.75 & 0.92 & 2.21 & 37.6 & NS \\
\hline $4 \times B$ & 1.58 & 0.44 & 1.63 & 24.8 & NS \\
\hline $4 \times \mathrm{Mn}+4 \times \mathrm{B}$ & 1.5 & 0.9 & 1.79 & 32.3 & NS \\
\hline$P$ value & NS & NS & NS & NS & \\
\hline
\end{tabular}

${ }^{\mathrm{z}}$ A field box contains $40.82 \mathrm{~kg}$ of fruit.

${ }^{y_{2}} 2017$ yields were significantly reduced by a severe PFD (post-bloom fruit drop disease caused by Colletotrichum acutatum) infection.

${ }^{\mathrm{x}}$ Cumulative column provides the total number of boxes of fruit per 12 trees receiving each treatment produced during the two seasons after treatments were implemented.

NS indicates not significant.

Table 8. Ct values of CLas detection in leaves in Nov. 2017.

\begin{tabular}{ll}
\hline Treatment & Ct value $^{z}$ \\
\hline $4 \times \mathrm{Mn}$ & $32.7 \mathrm{a}$ \\
Harrell's $^{\circledR}+2 \times \mathrm{Mn}+2 \times \mathrm{B}$ & $30.3 \mathrm{ab}$ \\
Harrell's $^{\circledR}+2 \times \mathrm{B}$ & $29.5 \mathrm{abc}$ \\
Harrell's $^{\circledR}$ & $29.3 \mathrm{abc}$ \\
$4 \times \mathrm{B}$ & $28.1 \mathrm{abc}$ \\
Harrell's & ${ }^{\circledR}+2 \times \mathrm{Mn}$ \\
$4 \times \mathrm{Mn}+4 \times \mathrm{B}$ & $27.6 \mathrm{abc}$ \\
Control & $23.8 \mathrm{bc}$ \\
\hline
\end{tabular}

zMeans separation by Tukey's honestly significant difference test $(P \leq 0.05)$.

tolerance to manganese deficiency and toxicity when grown in bauxite residue sand. Plant Soil 249:287-296.

Graham, J.H., E. Johnson, K.M. Gerberich, and D.B. Bright. 2016. Fertigation and soil acidification sustain root density of huanglongbing-infected trees in Florida citrus groves. American Phytopathological Society.

Graham, J.H., E.G. Johnson, T.R. Gottwald, and M.S. Irey. 2013. Presymptomatic fibrous root decline in citrus trees caused by Huanglongbing and potential interaction with Phytophthora spp. Plant Dis. 97:1195-1199.

Grosser, J.W. and G.A. Barthe. 2015. Soil applied controlled release fertilizer (CRF) treatments impact the health and growth of HLB infected trees - results from greenhouse and field experiments. In: International Research Conference HLB IV.

Halbert, S. 2005. The discovery of Huanglongbing in Florida. In: Proceedings of the Second International Citrus Canker and Huanglongbing Research Workshop. Orlando, Florida, p. 50 .

Hänsch, R. and R.R. Mendel. 2009. Physiological functions of mineral micronutrients $(\mathrm{Cu}, \mathrm{Zn}$, $\mathrm{Mn}, \mathrm{Fe}, \mathrm{Ni}, \mathrm{Mo}, \mathrm{B}, \mathrm{Cl})$. Curr. Opin. Plant Biol. 12:259-266

Islam, K.M.S., D.G. Edwards, and C.J. Asher. 1980. $\mathrm{pH}$ optima for crop growth. Plant Soil 54:339-357.
Jacoby, R., M. Peukert, A. Succurro, A. Koprivova, and S. Kopriva. 2017. The role of soil microorganisms in plant mineral nutrition-Current knowledge and future directions. Front. Plant Sci. 8:1-19.

Johnson, E.G., J. Wu, D.B. Bright, and J.H. Graham. 2014. Association of 'Candidatus Liberibacter asiaticus' root infection, but not phloem plugging with root loss on huanglongbingaffected trees prior to appearance of foliar symptoms. Plant Pathol. 63:290-298.

Kim, J.-S., U.S. Sagaram, J.K. Burns, J.-L. Li, and N. Wang. 2009. Response of sweet orange (Citrus sinensis) to "Candidatus Liberibacter asiaticus" infection: Microscopy and microarray analyses. Phytopathology 99:50-57.

Li, W., J.S. Hartung, and L. Levy. 2006. Quantitative real-time PCR for detection and identification of Candidatus Liberibacter species associated with citrus huanglongbing. J. Microbiol. Methods 66:104-115.

Marschner, H. 1995. Mineral Nutrition of Higher Plants. Academic Press, London.

Millaleo, R., M. Reyes-Diaz, A. Ivanov, M. Mora, and M. Alberdi. 2010. Manganese as essential and toxic element for plants: Transport, accumulation and resistance mechanisms. J. Soil Sci. Plant Nutr. 10:470-481.

Mittler, R. 2002. Oxidative stress, antioxidants and stress tolerance. Trends Plant Sci. 7:405-410.

Morgan, K.T., R.E. Rouse, and R.C. Ebel. 2016. Foliar applications of essential nutrients on growth and yield of 'Valencia' sweet orange infected with Huanglongbing. HortScience 51:1482-1493.

Navarro, J.M., S. Andujar, B. Garcĩa-Olmos, M. Rodrĩguez-Morán, O. Pérez-Tornero, and A. Morte. 2011. Arbuscular mycorrhizal fungi influence the response of citrus rootstock seedlings to salinity. Acta Hort. 922:245-252.

Nguyen, M.N., K.M. Lukaszewsk, and D.G. Blevins. 1993. IAA oxidase activity in squash root may be regulated by boron and manganese interaction. In: Plant Physiology. p. S.7.

Nwugo, C.C., H. Lin, Y. Duan, and E.L. Civerolo. 2013. The effect of 'Candidatus Liberibacter asiaticus' infection on the proteomic profiles and nutritional status of pre-symptomatic and symptomatic grapefruit (Citrus paradisi) plants. BMC Plant Biol. 13:59.

Obreza, T.A. and R.E. Rouse. 1993. Fertilizer effects on early growth and yield of Hamlin orange trees. HortScience 28:111-114.

Obreza, T.A., R. Rouse, and E.A. Hanlon. 2006. Advancements with controlled-release fertilizers for Florida citrus production: 1996-2006. SL-243. University of Florida Institute of Food and Agricultural Sciences, Gainesville.

Pitino, M., C.M. Armstrong, and Y. Duan. 2017. Molecular mechanisms behind the accumulation of ATP and $\mathrm{H} 2 \mathrm{O} 2$ in citrus plants in response to 'Candidatus Liberibacter asiaticus' infection. Hort. Res. 4:17040.

Pittman, J.K. 2005. Managing the manganese: Molecular mechanisms of manganese transport and homeostasis. New Phytol. 167:733-742.

Ramadi, S. and S. Kannan. 1974. Effects of certain cations on Manganese absorption by excised rice roots. Commun. Soil Sci. Plant Anal. 5:435-439.

Sattelmacher, B., J. Gerendds, K. Thoms, T. Marumoto, J.P.E. Anderson, and K.H. Domsch. 1982. Mineralization of nutrients from soil microbial biomass. Soil Biol. Biochem. 33: 469-475.

Spann, T.M. and A.W. Schumann. 2009. The role of plant nutrients in disease development with emphasis on citrus and Huanglongbing. Proc. Fla. State Hort. Soc. 122:169-171.

USDA-NASS. 2017. Statistics of fruits, tree nuts, and horticultural specialties. In: Agricultural Statistics 2017. United States Government Printing Office, Washington, DC.

Wang, Z., Y. Yin, H. Hu, Q. Yuan, G. Peng, and Y. Xia. 2006. Development and application of molecular-based diagnosis for "Candidatus Liberibacter asiaticus", the causal pathogen of citrus huanglongbing. Plant Pathol. 55:630 638 .

Zhong, Y., C.Z. Cheng, N.H. Jiang, B. Jiang, Y.Y. Zhang, B. Wu, M.L. Hu, J.W. Zeng, H.X. Yan, G.J. Yi, and G.Y. Zhong. 2015. Comparative transcriptome and iTRAQ proteome analyses of citrus root responses to candidatus liberibacter asiaticus infection. PLoS One 10:1-21. 


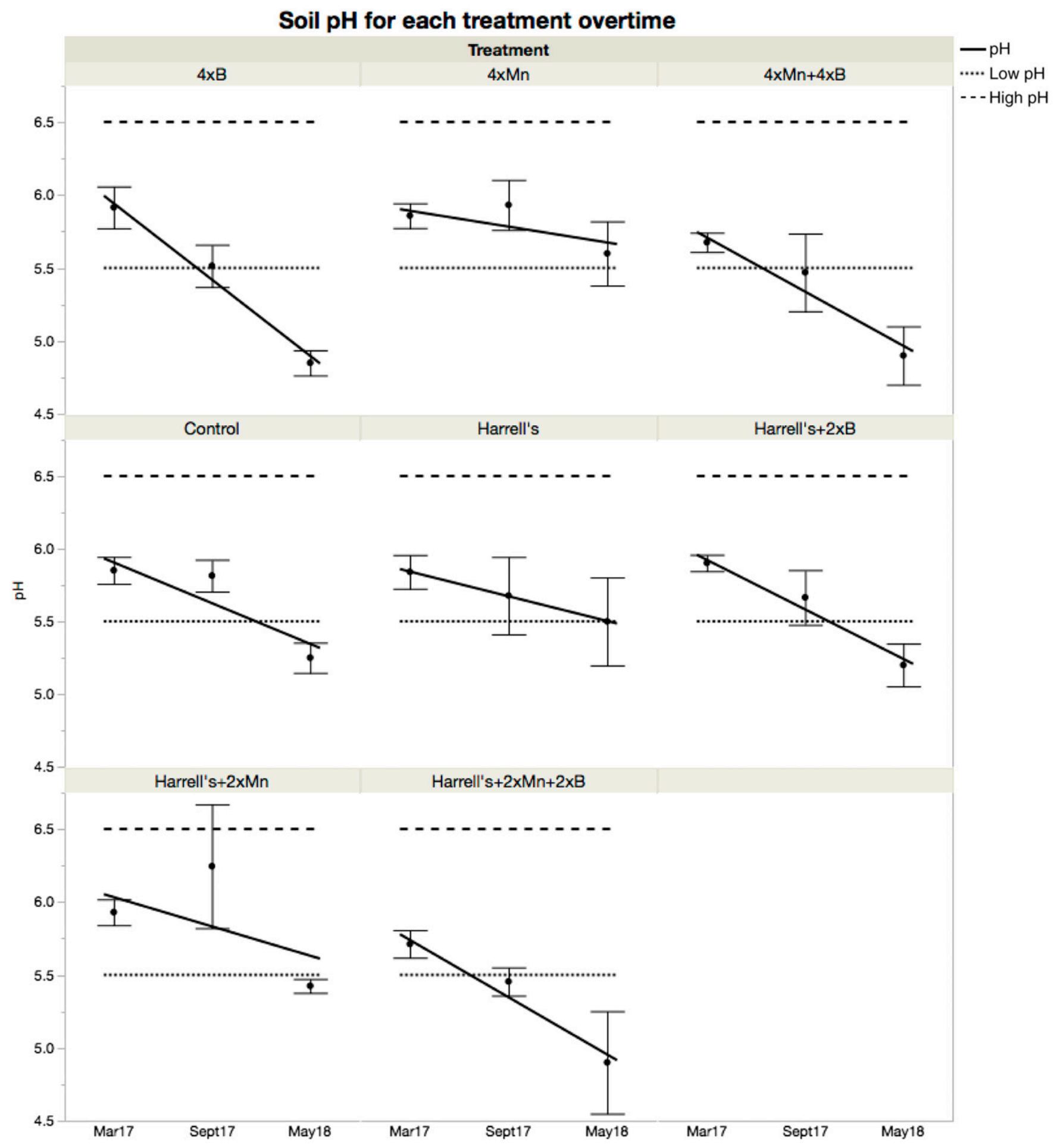

Each error bar is constructed using 1 standard error from the mean.

Fig. 9. Mean $\mathrm{pH}(\mathrm{n}=12)$ for all treatments during Mar. 2017, Sept. 2017, and May 2018. Horizontal lines correspond to the best $\mathrm{pH}$ range for nutrient absorption (high and low: 6.5 and 5.5, respectively). 
Supplemental Table 1. Fertilizer and psyllid control spray schedule for the 2016, 2017, and 2018 seasons

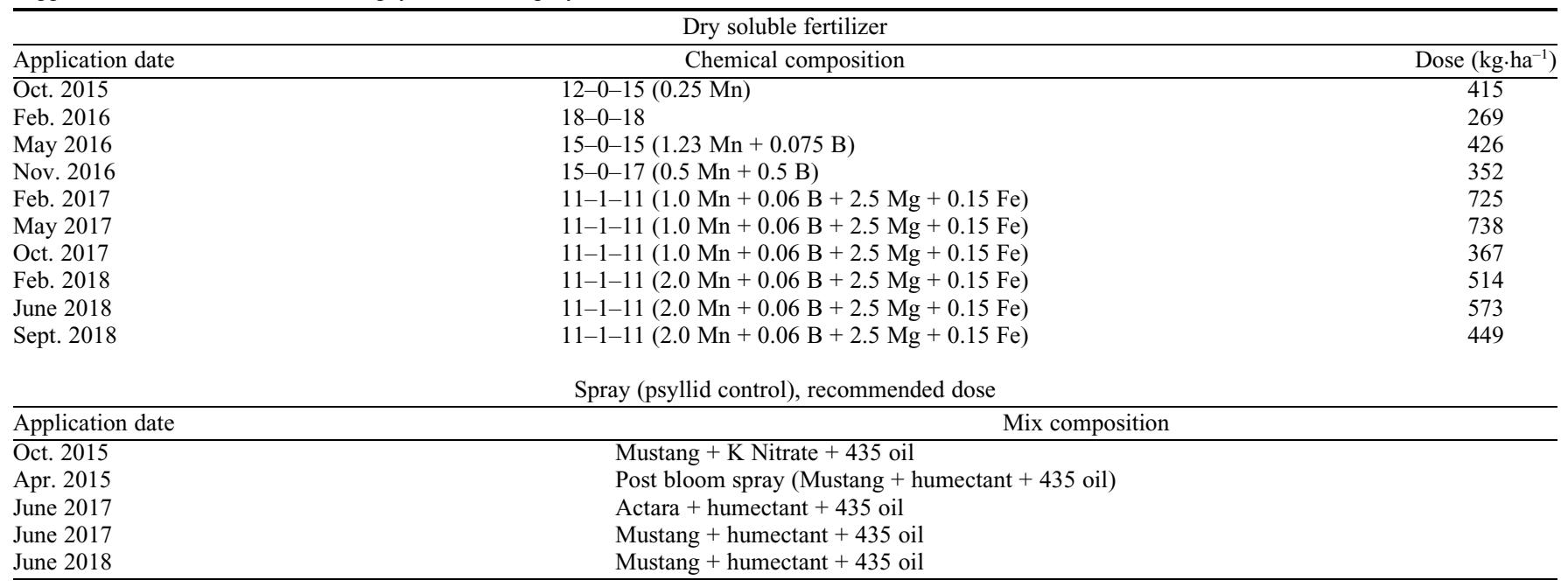




\begin{tabular}{|c|c|}
\hline Nutrient & Percent \\
\hline Total Nitrogen & $12.0000 \%$ \\
\hline Ammoniacal Nitrogen* & $4.3620 \%$ \\
\hline Urea Nitrogen* & $0.8100 \%$ \\
\hline Soluble Potash $\left(\mathrm{K}_{2} \mathrm{O}\right)^{*}$ & $9.0000 \%$ \\
\hline Calcium (Ca) & $4.5270 \%$ \\
\hline $\begin{array}{l}\text { Magnesium }(\mathrm{Mg}) \\
0.792 \% \text { Water-Soluble Magnesium }(\mathrm{Mg})\end{array}$ & $0.7920 \%$ \\
\hline $\begin{array}{l}\text { Iron }(\mathrm{Fe}) \\
0.088 \% \text { Water-soluble iron }(\mathrm{Fe}) \\
0.32 \% \text { Chelated Iron }(\mathrm{Fe})\end{array}$ & $1.0880 \%$ \\
\hline $\begin{array}{l}\text { Manganese }(\mathrm{Mn}) \\
0.065 \% \text { Water-Soluble Manganese }(\mathrm{Mn})\end{array}$ & $0.9200 \%$ \\
\hline Molybdenum (Mo) & $0.0060 \%$ \\
\hline $\begin{array}{l}\text { Zinc }(\mathrm{Zn}) \\
\quad 0.038 \% \text { Water-soluble zinc }(\mathrm{Zn})\end{array}$ & $0.7130 \%$ \\
\hline Chlorine $(\mathrm{Cl})$, no more than & $2.2490 \%$ \\
\hline
\end{tabular}

